\title{
Maciej Etel
}

University of Bialystok

\section{ACQUISITION AND LOSS OF \\ THE PUBLIC LAW STATUS OF ENTREPRENEUR - INTERPRETATION PROBLEMS OF PUBLIC COMMERCIAL LAW IN POLAND}

\begin{abstract}
The obligation of the legalization of entrepreneurial activity from Article 14 of The Act of July 2, 2004 on the freedom of entrepreneurial activity caused deliberations regarding constitutive or declarative character of the legalization entry and as a result, created a problem with indication of the moment when the public law status of an entrepreneur is acquired (or respectively lost). The answer to the question whether Central Register and Information of Entrepreneurial Activity or the register of entrepreneurs of the National Court Register have also the creation function incites many controversies and is subject to discussions, in the process of which two main standpoints were formed. It is also important to note that the resolution of the discussed issue not only holds scientific value, but above all, it has significant importance in practice. Therefore, it is necessary and even essential. Furthermore, it is typical for this issue that concerns related thereto and arguments raised during the discussion have their basis in the legislation in force and in fact, encapsulate the favoured path of its interpretation.
\end{abstract}

\section{Introduction - the essence of the problem}

The Act on the Freedom of Entrepreneurial Activity (ustawa z 2 lipca z 2004 o swobodzie działalności gospodarczej (Dz. U. z 2010 Nr 220, poz. 1447 t.j.)) stipulates the rules of undertaking, engaging in and terminating entrepreneurial activity on the territory of the Republic of Poland. Under Article 14 of this Act (Dz. U. z 2010 Nr 220, poz. 1447 t.j.), the basic obligation of the entrepreneur is the legalization of entrepreneurial activity, which takes place by a registration entry in the appropriate register - Central Register and Information of Entrepreneurial Activity (Centralna Ewidencja i Informacja o Działalności Gospodarczej, CEIDG) or the Na- 


\section{Maciej Etel}

tional Court Register of Entrepreneurs (rejestr przedsiębiorców Krajowego Rejestru Sądowego, KRS). In addition, Article 14 of Act on the Freedom of Entrepreneurial Activity (Dz. U. z 2010 Nr 220, poz. 1447 t.j.) decides registers applicability based on personal criterion. It indicates that CEIDG, regulated in detail by Articles 23-39 of Act on the freedom of entrepreneurial activity (Dz. U. z $2010 \mathrm{Nr} 220$, poz. 1447 t.j.), is applicable in regard to legalization of natural persons' entrepreneurial activity. At the same time, the National Court Register hereinafter (Krajowy Rejestr Sądowy, KRS) register of entrepreneurs, structured according to the (ustawa z 20 sierpnia 1997 - o Krajowym Rejestrze Sądowym. (Dz. U. z 1997 Nr 121, poz. 769 ze zm.)). Act on the National Court Register hereinafter is deemed applicable to the legalization of entrepreneurial activity of legal persons and of entities that do not have a legal personality but are granted legal capacity by an act of law.

In this way, typical for the so called "constitution of entrepreneurial activity", Act on the freedom of entrepreneurial activity determines the coexistence on Polish territory of two registers applicable for the legalization of entrepreneurial activity. (Stawecki, 2004, p. 31 and next).

It is necessary to emphasize that, despite differences in the normative structure, CEIDG and the KRS register of entrepreneurs have identical functions: they serve to legalize entrepreneurial activity, which ensures (or at least intends to ensure) access to information about entrepreneurial activity and entrepreneurs, thus these registers indirectly secure proper performance of functions of the state in the economy. (Kosikowski, 2010, p. 117203). The legal rationale for the obligation of legalization of entrepreneurial activity (equated with the register entry) expressed in this way does not raise any concerns and is commonly accepted in the public commercial law jurisprudence.

The above does not mean, however, that the issue of legalization of entrepreneurial activity is free of any doubt. On the contrary, the obligation from Article 14 of Act on the Freedom of Entrepreneurial Activity (Dz. U. z $2010 \mathrm{Nr} 220$, poz. 1447 t.j.) caused deliberations regarding constitutive or declarative character of the legalization entry and as a result, created a problem with indication of the moment when the public law status of an entrepreneur is acquired (or respectively - lost). The answer to the question whether, apart from the abovementioned functions, CEIDG and the KRS register of entrepreneurs have also the establishing function - in other words, does the registration entry into CEIDG or into the KRS register of entrepreneurs create the entrepreneur - incites many controversies and is subject to discussions, in the process of which two main standpoints were formed. 
It is important to note that the resolution of the discussed issue not only holds scientific value (jurisprudential and academic), but above all, it has significant importance in practice. ${ }^{1}$ Therefore, it is necessary and even essential. It is typical for this issue that concerns related thereto and arguments raised during the discussion have their basis in the legislation in force and in fact, encapsulate the favoured path of its interpretation.

\section{Declarative character of the registration entry into CEIDG and into the KRS register of entrepreneurs}

The first standpoint, indicating a declarative character of the registration entry into CEIDG and into the KRS register of entrepreneurs, is based on the literal interpretation of the systemic legal definition of the term "entrepreneur".

According to Article 4 of Act on the Freedom of Entrepreneurial Activity (Dz. U. z 2010 Nr 220, poz. 1447 t.j.) an entrepreneur is a natural person, legal person or entity that is not a legal person but it is granted legal capacity by a separate act of law, who engages in entrepreneurial activity in its own name. It is not difficult to notice that the scope of the meaning of the term "entrepreneur" in Article 4 of Act on the Freedom of Entrepreneurial Activity (Dz. U. z 2010 Nr 220, poz. 1447 t.j.) is indicated by describing the criteria decisive for identification. These are: 1) personal criterion - indicating the categories of entities that may be recognized as entrepreneurs, ${ }^{2}$ 2) subjective criterion - describing the activity of an entrepreneur, ${ }^{3} 3$ ) functional criterion - providing that only a natural person, legal person or entity that does not have legal personality but is granted legal capacity by a separate act of law, which engages in entrepreneurial activity in its own name, may be classified as an entrepreneur. (Gronkiewicz-Waltz, 2009, p. 216).

Referring to the criteria described in Article 4 of Act on the Freedom of Entrepreneurial Activity the supporters of the first standpoint claim that the fulfilment of the criteria indicated in the legal definition, which is, above all, engaging in entrepreneurial activity in one's own name, determines the acquisition of the status of an entrepreneur. Consequently, they deem the registration entry into CEIDG or into the KRS register of entrepreneurs to have only declarative character. This is because they believe that it does not create an entrepreneur, as it only constitutes a condition to undertake entrepreneurial activity, which confirms that status, and allows engagement in entrepreneurial activity. 


\section{Maciej Etel}

The above presented view, which seemed to be dominant in the jurisprudence of the public commercial law (Katner, 2003, p. 60-61; Szydło, 2005, p. 101-104; Czepita, Kuniewicz, 2007, p. 62; Gronkiewicz-Waltz, Jaroszyński, 2009, p. 285; Pawełczyk, 2007, p. 39-40; Zamojski, 2009, p. 250-251; Pawełczyk, 2005, p. 38-39), is also confirmed by the judicial decisions. ${ }^{4}$ Its correctness is reflected by the idea that the lack of registration entry in CEIDG or in the KRS register of entrepreneurs should not free the entities actually engaged in entrepreneurial activity from the requirements imposed by the law on entrepreneurs (Walaszek-Pyziol, 1999, p. 5), or that the lack of registration entry does not mean that the entity is not an entrepreneur, when it does in fact engage in entrepreneurial activity but it does not register it. (wyrok Wojewódzkiego Sądu Administracyjnego w Warszawie z dnia 7 listopada 2007, VI SA/Wa 1852/05).

In this context, the view regarding the declarative character of legalization entry has a normative justification (the wording of Article 4 of Act on the Freedom of Entrepreneurial Activity - Dz. U. z $2010 \mathrm{Nr} 220$, poz. 1447 t.j.) and ensures desired effects in practice. For the purpose of classifying an entity - one that engages in entrepreneurial activity in its own name, but without a registration entry in CEIDG or the KRS register of entrepreneurs - as an entrepreneur is to enforce restrictions that constrain all entrepreneurs (and given entrepreneurial activity).

\section{Constitutive character of the registration entry into CEIDG and into the KRS register of entrepreneurs}

However, it is important to note that the issue of the character of the registration entry into CEIDG or into the KRS register of entrepreneurs and as a result the issue of acquisition and loss of the public law status of an entrepreneur - is also interpreted differently. According to the second standpoint, the legalization entry has a constitutive character. ${ }^{5}$ It means that it creates an entrepreneur and it should be identified with the moment of acquisition of the public law status as an entrepreneur. (Katner, 2003, p. 60). Also this statement is supported normatively - it takes its base from Article 4 of Act on the Freedom of Entrepreneurial Activity (Dz. U. z 2010 Nr 220, poz. 1447 t.j.) read with Article 14 and Article 6 of that Act.

Article 6 section 1 of Act on the Freedom of Entrepreneurial Activity, ${ }^{6}$ while referring to the constitutionally guaranteed principle of the freedom of entrepreneurial activity, ${ }^{7}$ indicates that this freedom should be perceived in three stages i.e. undertaking, engaging in and terminating entrepreneurial 
activity, which even though inseparable (focusing on consecutive scopes of economic freedom), can be interpreted independently. (Walaszek-Pyzioł, 1994, p. 36-48; Kosikowski, 2011, p. 63). Considering the above, it is then important to note that Article 14 of Act on the freedom of entrepreneurial activity, by stipulating the legalization obligation, forms the stage of undertaking the activity, ${ }^{8}$ whereas Article 4 of the Act on the Freedom of Entrepreneurial Activity, by forming a legal definition of an entrepreneur, already refers to the freedom of engaging in entrepreneurial activity. ${ }^{9}$ Consequently, the entity engaging, in its own name in entrepreneurial activity Article 4 of Act on the Freedom of Entrepreneurial Activity - (Dz. U. z 2010 Nr 220, poz. 1447 t.j.) is an entrepreneur, where sine qua non condition of legally engaging in the activity is to previously legally undertake the activity, which was made dependant on prior acquisition of the appropriate registration entry in CEIDG or in the KRS register of entrepreneurs - Article 14 of Act on the Freedom of Entrepreneurial Activity (Dz. U. z 2010 $\mathrm{Nr} 220$, poz. 1447 t.j.). It means that if the fundamental restriction of engaging in entrepreneurial activity is engaging in it in accordance to the law in force (i.e. by the legalization entry), then the public law status of an entrepreneur is acquired by an entity at the moment of the acquisition of the entry. ${ }^{10}$

Also, this standpoint (similar to the first of the ones described) is confirmed by judicial decisions. The courts decided that the status of an entrepreneur is obtained by an entity through meeting the criteria indicated by Article 4 and Article 2 of Act on the Freedom of Entrepreneurial Activity (Dz. U. z 2010 Nr 220, poz. 1447 t.j.), however, it is also essential to meet a formal condition, which is to acquire legalization entry, as it is the entry that creates the entity and without it the existence of the entrepreneur remains, in principle, without legal significance. ${ }^{11}$ This conclusion is not contradicted by the fact that the entry does not always equal actual engagement in entrepreneurial activity, but it only constitutes a legal possibility of engagement and substantiates the engagement.12 It is important to remember that it is the entry that has the decisive significance from the perspective of certainty and security of legal transactions - therefore, as an obligation it constitutes a priority for any entity interested in engaging in entrepreneurial activity. ${ }^{13}$

Recognizing the constitutive character of the registration entry in CEIDG or in the KRS register of entrepreneurs is also supported by the legal construction of suspension of entrepreneurial activity. In the light of Article 14a of Act on the Freedom of Entrepreneurial Activity (Dz. U. z 2010 $\mathrm{Nr} 220$, poz. 1447 t.j.), an entity that is not in fact engaged in entrepreneurial 


\section{Maciej Etel}

activity, but refraining from engagement therein,${ }^{14}$ does not lose this status and is still treated as an entrepreneur. ${ }^{15}$

At the same time, it is necessary to note that the thesis regarding constitutive character of the registration entry may incite doubts. On one hand, the obligation of legalization does not include everyone entitled to and engaged in entrepreneurial activity ${ }^{16}$ or as a matter of law accepts situations when an entity engaged in entrepreneurial activity is subject to registration entry in any register. ${ }^{17}$ On the other hand, entities that are not engaged in entrepreneurial activity are obligated to acquire a registration entry and (based on the obligatory entry) are ex lege classified as entrepreneurs. ${ }^{18}$ Furthermore, material and personal exemptions from the categories: entrepreneurial activity and entrepreneur, provided by the law, lead to a situation where it is possible not to be an entrepreneur, despite engaging in entrepreneurial activity in one's own name or a type of entrepreneurial activity may not match all the relevant characteristics from Article 2 of Act on the freedom of entrepreneurial activity (Kosikowski, 2010, p. 230). The situation is additionally complicated by the fact that CEIDG and the KRS registers of entrepreneurs are not the only registers that may determine legality of the engagement in entrepreneurial activity. (Sowiński, 2007, p. 225 and next). Moreover, in practice there are often instances when an entity which is displayed in the register is not, in fact, engaged in entrepreneurial activity. ${ }^{19}$

\section{Conclusions - creation and application of the law}

The abovementioned constitute the basis of the argument for rejecting the view on the constitutive character of the registration entry in CEIDG and in the KRS register of entrepreneurs. At the same time, they confirm the correctness of the standpoint, which acknowledges the criteria indicated in the legal definition of Article 4 of Act on the Freedom of Entrepreneurial Activity (Dz. U. z $2010 \mathrm{Nr} 220$, poz. 1447 t.j.) as determining.

However, it is important to note that, when deciding on the issue of the public law status of an entrepreneur, the main assumption of the statement regarding the determining role of the criteria included in the legal definition of Article 4 of Act on the Freedom of Entrepreneurial Activity (Dz. U. z 2010 Nr 220, poz. 1447 t.j.) is classifying an entity, which engages in entrepreneurial activity in its own name but without a registration entry in CEIDG or in the KRS register of entrepreneurs, as an entrepreneur. ${ }^{20}$ Thus this statement has important significance in practice but in fact does 
not resolve the issue of acquisition or loss of the public law status of an entrepreneur. It is a consequence of ambiguity, contradiction and lack of precision that characterize this branch of national law.

It is also important to emphasize that this statement is a result of the literal interpretation of Article 4 Act on the Freedom of Entrepreneurial Activity (Dz. U. z 2010 Nr 220, poz. 1447 t.j.). However, it is necessary to remember that, even though during the process of interpretation of the law the literal interpretation takes priority (Oliwniak, 2007, p. 126), this priority is not absolute. Despite the supplementary (complementary and supporting) function attributed to the systemic and functional interpretation, they play a significant role. They resolve doubts that arise from the language base, they allow a choice between two different results of the literal interpretation, modifying these results by taking into account the character of the legal system and the intentions of the legislator (legal rationale), and even justify deviation from the literal meaning. ${ }^{21}$

Considering the above, in particular the intended reasons for constituting the obligation of legalization of entrepreneurial activity in the light of Article 14 Act on the Freedom of Entrepreneurial Activity (Dz. U. z 2010 $\mathrm{Nr} 220$, poz. 1447 t.j.), the correct result of interpretation is the recognition of the binding role of the registration entry in CEIDG or the KRS register of entrepreneurs. Firstly, it is supported by the wording of the applicable norms, in other words, it is a result of literal interpretation. Secondly, it takes into account the goals intended by the legislator and character of the legal system in the broadest way, that is, it corrects the result of the literal interpretation by referring to functional and systemic values.

This conclusion is not denied by the flaws or lacks of the law that specifies the rules for undertaking, engaging in and terminating entrepreneurial activity. They only confirm a significant conclusion, according to which legislation should be a conscious and well considered process. The fundamental duty of the legislator is then to create good law, which means making resolutions that are essentially appropriate and expressing them in a precise and communicative way in the legal acts creating a clear and coherent system. (Wronkowska, Zieliński, 2004, p. 7). For good law is a fundamental condition for the correct interpretation of legal norms. ${ }^{22}$

Summing up, it may be concluded that the problem of acquisition and loss of the public law status as an entrepreneur is mainly the result of the activity of irrational legislators, who by their actions in the sphere of law making, considerably impede and at times, even render correct interpretation and application of the law. Resolution of the issue discussed in this study cannot be limited to the creation, acceptance or defense of a cer- 


\section{Maciej Etel}

tain concept but should consist in modernization of the rules of legalization of entrepreneurial activity. It is particularly crucial, when the flaws of the current legislation in force have been recognized.

\section{N O T E S}

1 Resolving the issue of acquisition and loss of the public law status of an entrepreneur is directly connected with the enforcement by the state and its institutions of the obligations provided by the law and imposed on entrepreneurs. For it is clear that the obligations imposed on entrepreneurs should only be enforced on entrepreneurs and not on entities that do not have their status.

2 According to Article 4 of Act on the Freedom of Entrepreneurial Activity (Dz. U. z 2010 Nr 220, poz. 1447 t.j.) only a natural person, a legal person or an entity that does not have legal personality but it is granted legal capacity by a separate act of law can be classified as entrepreneurs.

3 According to Article 4 of Act on the Freedom of Entrepreneurial Activity (Dz. U. z $2010 \mathrm{Nr} 220$, poz. 1447 t.j.) it is the entrepreneurial activity in the meaning of Article 2 of that Act. According to Article 2 of Act on the Freedom of Entrepreneurial Activity entrepreneurial activity is a manufacturing, construction, commercial, service activity or activity that consist in seeking, recognizing and extracting mineral deposits as well as professional activity directed at achieving profit, conducted in an organized and continuous way.

${ }^{4}$ See sentences of (wyrok Naczelnego Sądu Administracyjnego z dnia 25 października 2006, II GSK 179/06), see (wyrok Wojewódzkiego Sądu Administracyjnego w Warszawie z dnia 7 listopada 2006, VI SA/Wa 1852/05), (wyrok Wojewódzkiego Sądu Administracyjnego w Warszawie z dnia 21 marca 2006, VI SA/Wa 2215/05), (wyrok Wojewódzkiego Sądu Administracyjnego w Warszawie z dnia 4 grudnia 2007, VII SA/Wa 1578/07, wyrok Wojewódzkiego Sądu Administracyjnego w Warszawie z dnia 20 listopada 2007, VII SA/Wa 1444/07), (wyrok WSA w Warszawie z dnia 9 listopada 2007, (VII SA/Wa 1394/07)).

${ }^{5}$ It is important to emphasize that the entry is not an administrative decision but constitutes a perfunctory action. Contrary to the previous legal regulation, in current state of legislation the entry does not grant the entrepreneur a right to engage in entrepreneurial activity nor does it lift a general ban of engaging in entrepreneurial activity. See (Niezgódka-Medkova, 1990, p. 112-116); (Kozioł, 2009, p. 35-49); (Waligórski, 2006, p. 112); (Kosikowski, 2010, p. 149); (Szydło, 2004, p. 167-168); (Powałowski, 2007, p. 126); (Zdyb, 1997, p. 367-368); (Powałowski, 2006, p. 91-97); (otherwise: Pater, 1989, p. 86-88).

6 According to Article 6 section 1 of Act on the Freedom of Entrepreneurial Activity (Dz. U. z $2010 \mathrm{Nr}$ 220, poz. 1447 t.j.) undertaking, engaging in and terminating entrepreneurial activity is free for everyone on equal legal terms, providing that the requirements stipulated by the law are kept.

7 In this respect it duplicates the content of the Constitution of the Republic of Poland of 1997 (Konstytucja Rzeczypospolitej Polskiej z dnia 2 kwietnia 1997 (Dz. U. 1997 Nr 78, poz. 483 ze zm.)); see Article 20 read with Article 22 of the Polish Constitution.

8 According to Article 14 of Act on the Freedom of Entrepreneurial Activity (Dz. U. z 2010 Nr 220, poz. 1447 t.j.) the entrepreneur can undertake entrepreneurial activity on the day $(\ldots)$.

9 According to Article 4 Act on the Freedom of Entrepreneurial Activity (Dz. U. z 2010 $\mathrm{Nr} 220$, poz. 1447 t.j.) an entrepreneur is (...) engaged in entrepreneurial activity in its own name. 


\section{Acquisition and Loss of the Public Law Status of Entrepreneur...}

10 (Kosikowski, 2010, p. 230); See wyrok Naczelnego Sądu Administracyjnego z dnia 10 października 2006, II GSK 140/06), which states that "the actions of the public administration institution of entering an entry into the register creates a legal possibility of engaging in entrepreneurial activity, which is a condition of its undertaking".

11 (Wyrok Wojewódzkiego Sądu Administracyjnego w Warszawie z dnia 22 stycznia 2008, VI SA/Wa 1957/07); (wyrok Sądu Okręgowego w Białymstoku z dnia 15 stycznia 2009, VII GC 116/08; compare (Szanciło, 2005, p. 6).

12 Compare (wyrok Naczelnego Sądu Administracyjnego z dnia 21 czerwca 2007, II GSK 70/07), (wyrok Naczelnego Sądu Administracyjnego z dnia 10 października 2006, II GSK 140/06), (wyrok Naczelnego Sądu Administracyjnego z dnia 25 października 2006, II GSK 179/06), (wyrok Wojewódzkiego Sądu Administracyjnego w Warszawie z dnia 21 marca 2006, VI SA/Wa 2215/05), (wyrok Wojewódzkiego Sądu Administracyjnego w Warszawie z dnia 28 stycznia 2009, VII SA/Wa 1374/08), (wyrok Wojewódzkiego Sądu Administracyjnego w Warszawie z dnia 4 grudnia 2007, VII SA/Wa 1578/07), (wyrok Wojewódzkiego Sądu Administracyjnego w Warszawie z dnia 20 listopada 2007, VII SA/Wa 1444/07), (wyrok Wojewódzkiego Sądu Administracyjnego w Warszawie z dnia 9 listopada 2007, VII SA/Wa 1394/07)).

13 Lack of information about termination of entrepreneurial activity creates a presumption that the activity is still conducted and that the entity is still an entrepreneur; see the (wyrok Sądu Najwyższego z dnia 20 października 2005, II CK 120/05), (wyrok Naczelnego Sądu Administracyjnego z dnia 12 stycznia 1994, III SA 835/93), (wyrok Naczelnego Sądu Administracyjnego z dnia 22 października 1998, II SA 645/98), (Bieniek-Koronkiewicz, Sieńczyło-Chlabicz, 2002, p. 15-24).

14 After meeting material and procedural conditions which were stipulated to determine the possibility of suspending entrepreneurial activity.

15 The lack of actual engagement in entrepreneurial activity does not affect the public law status of an entrepreneur, which confirms the fact that the status is dependent on the registration entry in CEIDG or entry in the KRS register of entrepreneurs.

16 According to Article 3 of Act on the National Court Register (Dz. U. z 1997 Nr 121, poz. $769 \mathrm{ze} \mathrm{zm}$.) the register covers entities, which are required by a provision of law to acquire a registration entry into this register. Consequently, inter alia church legal persons, universities, cultural institutions and healthcare enterprises, which are registered outside of the National Court Register system, are not bound by the obligation to acquire a registration entry into the KRS register of entrepreneurs even when they engage in entrepreneurial activity; (Kosikowski, 2001, p. 63-65), (Kosikowski, 2010, p. 231), (Skubisz, Trzebiatowski, 2002, p. 8-21).

17 It pertains to a corporation in the process of formation, which, as the Article 14 section 4 of Act on the Freedom of Entrepreneurial Activity (Dz. U. z 2010 Nr 220, poz. 1447 t.j.) clearly states, may undertake entrepreneurial activity before the acquisition of the entry.

18 The obligation of registration in the KRS register of entrepreneurs binds different categories of entities, while all of the entities indicated in Article 36 of Act on the National Court Register (Dz. U. z 1997 Nr 121, poz. 769 ze zm.) are deemed entrepreneurs by the law, even if in practice they do not engage in entrepreneurial activity in their own name. In particular this pertains to commercial law corporations and research institutes, which may or may not have entrepreneurial activity as their subject of operations. Allowing for the possibility to engage in entrepreneurial activity does not equal the actual engagement; See (Kosikowski, 2001, p. 60-61), (Pawełczyk, 2005, p. 39-40). Otherwise (Zamojski, 2009, p. 250-251). 


\section{Maciej Etel}

19 This entity is characterized by the status of an entrepreneur and does not lose it until the moment of deletion from register, even though it does not match the conditions indicated in the legal definition. See (Kosikowski, 2010, p. 231).

20 Due to the necessity (obligation) to enforce obligations imposed on entrepreneurs and connected with entrepreneurial activity.

21 See more in (Morawski, 2010, p. 70-71). Compare the (orzeczenie Sądu Najwyższego z dnia 15 stycznia 2003, III PZP 20/02, uchwała siedmiu sędziów Sądu Najwyższego z dnia 21 maja 2004, I KZP 42/03), (wyrok Sądu Apelacyjnego w Warszawie z dnia 21 września 2004, II AKa 344/04).

22 (Morawski, 2010, p. 24). See (uchwała Sądu Najwyższego z dnia 20 stycznia 2000, I KZP 48/99), (wyrok Sądu Najwyższego z dnia 15 maja 2000, V KKN 88/00), (wyrok Wojewódzkiego Sądu Administracyjnego w Warszawie z dnia 21 grudnia 2004, III SA/Wa 1874/04).

\section{R E F E R E N C E S}

Bieniek-Koronkiewicz, E., Sieńczyło-Chlabicz, J. (2002). Skutki wpisu do Krajowego Rejestru Sądowego, Glosa 8, 15-24.

Czepita, S., Kuniewicz, Z. (2007). Wybrane problemy definiowania określenia "przedsiębiorca w prawie polskim. In Sławik K. (Ed.), Działalność gospodarcza - kluczowe problemy (p. 62). Warszawa: Difin.

Gronkiewicz-Waltz, H., Jaroszyński, K. (2009). Przedsiębiorca. In C. Banasiński et al. (Eds.). Prawo gospodarcze. Zagadnienia administracyjnoprawne (p. 216). Warszawa: LexisNexis.

Katner, W., J. (2003). Prawo działalności gospodarczej. Komentarz. Orzecznictwo. Piśmiennictwo. Warszawa: LexisNexis, 60-61.

Kosikowski, C. (2001). Przedsiębiorca. In J. Jacyszyn, C. Kosikowski (Eds.). Podstawy prawa gospodarczego. Warszawa: LexisNexis, 63-65.

Kosikowski, C. (2010). Publiczne prawo gospodarcze Polski i Unii Europejskiej. Warszawa: LexisNexis, 117-203, 230, 231.

Kosikowski, C. (2011). Ustawa o swobodzie działalności gospodarczej. Komentarz. Warszawa: LexisNexis, 63.

Kozioł, K. (2009). Rejestracja osób fizycznych prowadzących działalność gospodarczą - ewidencja działalności gospodarczej czy Krajowy Rejestr Sądowy? Samorzad Terytorialny 9, 35-49.

Morawski, L. (2010). Zasady wykładni prawa. Toruń: TNOiK "Dom Organizatora", $70-71$.

Niezgódka-Medkova, M. (1990). W kwestii charakteru wpisu do ewidencji działalności gospodarczej, Państwo i Prawo 1, 112-116.

Oliwniak, S.(2007). Stosowanie prawa. In A. Jamróz (ed.). Wstęp do prawoznawstwa. Białystok: Temida 2, 126. 
Pater, J. (1989). Postępowanie ewidencyjne w ustawie o działalności gospodarczej, Państwo i Prawo 7, 86-88.

Pawełczyk, M. (2005). Przedsiębiorca w świetle ustawy o swobodzie działalności gospodarczej. Radca Prawny 6, 38-39, 40.

Pawełczyk, M. (2007). Komentarz do art. 4 u.s.d.g. In A. Powałowski (Ed.), Ustawa o swobodzie dzialalności gospodarczej. Komentarz (pp. 39-40) Warszawa: WoltersKluwer.

Powałowski, A. (2006). Wpis do ewidencji działalności gospodarczej. Studia Prawnicze, 1, 91-97.

Powałowski, A. (2007). Komentarz do art. 7b p.d.g. In A. Powałowski (Ed.), Ustawa o swobodzie działalności gospodarczej. Komentarz (p. 126). Warszawa: WoltersKluwer.

Skubisz, R., Trzebiatowski, M. (2002). Kościelne osoby prawne jako przedsiębiorcy rejestrowi (na przykładzie osób prawnych kościoła katolickiego). Przeglad Prawa Handlowego 3, 8-21.

Sowiński, R. (2007). Rejestry i Ewidencje działalności gospodarczej i przedsiębiorców. Wrocław: Kolonia Limited, 225 and next.

Stawecki, T. (2004). Rejestry przedsiębiorców w Europie. Warszawa: Oficyna Wydawnicza, 31 and next.

Szanciło, T. (2005). Przedsiębiorca w prawie polskim. Przeglad Prawa Handlowego 3,6 .

Szydło, M. (2004). Ewidencja działalności gospodarczej jako administracyjny rejestr przedsiębiorców. Kwartalnik Prawa Publicznego 1, 167-168.

Szydło, M. (2005). Swoboda działalności gospodarczej. Warszawa: C.H. Beck, 101104.

Uchwała Sądu Najwyższego z dnia 15 stycznia 2003, III PZP 20/02, OSNP 2004, nr 1, poz. 4, Lex 57087.

Uchwała siedmiu sędziów Sądu Najwyższego z dnia 21 maja 2004, I KZP 42/03, OSP 2005, nr 1, poz. 7, Lex 106641.

Ustawa z 20 sierpnia 1997 - o Krajowym Rejestrze Sądowym. (Dz. U. z 1997 Nr 121, poz. 769 ze zm.).

Ustawa z 2 lipca z 2004 o swobodzie działalności gospodarczej (Dz. U. z 2010 Nr 220, poz. 1447 j.t.).

Walaszek-Pyzioł, A. (1994). Swoboda działalności gospodarczej. Studium prawne. Kraków: Księgarnia Akademicka, 36-48.

Walaszek-Pyzioł, A. (1999). Status prawny przedsiębiorcy w świetle projektu ustawy - Prawo działalności gospodarczej. Przeglad Ustawodawstwa Gospodarczego 5,5 .

Waligórski, M., A. (2006). Działalność gospodarcza w ujęciu prawa administracyjnego. Poznań: Forum Naukowe - Passat, 112.

Wronkowska, S., Zieliński, M. (2004). Komentarz do zasad techniki prawodawczej. Warszawa: Wydawnictwo Sejmowe, 7. 


\section{Maciej Etel}

Wyrok Naczelnego Sądu Administracyjnego z dnia 10 października 2006, II GSK 140/06, LEX nr 276711.

Wyrok Naczelnego Sądu Administracyjnego z dnia 12 stycznia 1994, III SA 835/93, LEX nr 43572.

Wyrok Naczelnego Sądu Administracyjnego z dnia 21 czerwca 2007, II GSK 70/07, LEX nr 338408.

Wyrok Naczelnego Sądu Administracyjnego z dnia 22 października 1998, II SA 645/98, LEX nr 43210.

Wyrok Naczelnego Sądu Administracyjnego z dnia 25 października 2006, II GSK 179/06, LEX nr 276729.

Wyrok Sądu Apelacyjnego w Warszawie z dnia 21 września 2004, II AKa 344/04, LEX nr 146672.

Wyrok Sądu Najwyższego z dnia 20 października 2005, II CK 120/05, LEX nr 167116.

Wyrok Sądu Okręgowego w Białymstoku z dnia 15 stycznia 2009, VII GC 116/08, LEX nr 522334.

Wyrok Wojewódzkiego Sądu Administracyjnego w Warszawie z dnia 20 listopada 2007, VII SA/Wa 1444/07, LEX nr 496336.

Wyrok Wojewódzkiego Sądu Administracyjnego w Warszawie z dnia 21 marca 2006, VI SA/Wa 2215/05, LEX nr 257125.

Wyrok Wojewódzkiego Sądu Administracyjnego w Warszawie z dnia 22 stycznia 2008, VI SA/Wa 1957/07, LEX nr 466055.

Wyrok Wojewódzkiego Sądu Administracyjnego w Warszawie z dnia 28 stycznia 2009, VII SA/Wa 1374/08, LEX nr 489317.

Wyrok Wojewódzkiego Sądu Administracyjnego w Warszawie z dnia 4 grudnia 2007, VII SA/Wa 1578/07, LEX nr 496344.

Wyrok Wojewódzkiego Sądu Administracyjnego w Warszawie z dnia 7 listopada 2006, VI SA/Wa 1852/05, LEX nr 312029.

Wyrok Wojewódzkiego Sądu Administracyjnego w Warszawie z dnia 9 listopada 2007, VII SA/Wa 1394/07, LEX nr 452355.

Zamojski, Ł. (2009). Ustawa o Krajowym Rejestrze Sadowym. Komentarz. Warszawa: LexisNexis, 250-251.

Zdyb, M. (1997). Komentarz do ustawy o działalności gospodarczej. Bydgoszcz: Branta, 367-368. 